\title{
College to career ready: Innovative practices that lead to integrated employment
}

\author{
Kelly R. Kelley* and Susan K. Buchanan \\ Western Carolina University, Cullowhee, NC, USA
}

Revised/Accepted November 2016

\begin{abstract}
.
BACKGROUND: With recent legislative and funding support from the Higher Education Opportunity Act (2008) and Higher Education Reform and Opportunity Act (2015), many colleges and universities are expanding to serve a wider range of students, including individuals with intellectual disability (ID).

OBJECTIVE: This practice brief shares how one fully inclusive postsecondary (PSE) program in the southeastern United States provides PSE and vocational training to successfully connect $80 \%$ of their program graduates to integrated employment outcomes after graduation with reported long-term success.

CONCLUSION: Details are shared on how the PSE program established more than 40 internships and collaborated with various employers, family members, natural supports, coworkers, and community members to achieve successful employment opportunities both during and after college experiences. Finally, specific innovative practices used in this PSE program related to a) career interests/assessments, b) person centered planning practices to determine support needs, c) advising and college course planning, d) setting up internships and paid work experiences, e) evaluation and observation of work performance, and f) connecting back to the community with video resumes are also shared.
\end{abstract}

Keywords: Integrated employment, vocational training, postsecondary education, person centered planning, intellectual disability

\section{Introduction}

In the last 30 years, colleges and universities have expanded learning opportunities to include a wide variety of students with differing abilities through the reauthorizations of the Higher Education Opportunity Acts. Until most recently, individuals with intellectual disabilities (ID) and their families had never thought about attending or living on college campuses to expand their independent living and employment skills. Instead, many had traditionally remained in school until they were 21 or 22 years old and then were sometimes served by community agencies after completing high school. While these

\footnotetext{
*Address for correspondence: Kelly R. Kelley, Western Carolina University, 152 Cordelia Camp Building, Cullowhee, NC 28723, USA. Tel.: +1 828227 3298; Fax: +1 828227 7170; E-mail: kkelley@email.wcu.edu.
}

services are beneficial, they have not always offered the experiences of life away from home and the associated opportunities of learning along side same-age peers without disabilities while experiencing employment, academic, social, and personal situations. PSE programs are rising to this learning opportunity and emerging across the United States to provide more age-appropriate and inclusive learning experiences for college age persons with ID. In addition, data are indicating that from these PSE experiences, individuals with ID are finding more positive paid employment outcomes with higher wages in comparison to individuals not attending PSE (Grigal et al., 2015).

One fully inclusive PSE program in the southeastern United States provides a two-year, on-campus living and learning experience for individuals between 18 and 25 years of age to address these gaps. Students live on-campus and complete requirements 
for a Certificate of Accomplishment. The Certificate is based on the successful completion of an Individual Plan for College Participation (IPCP) which includes goals related to academic access, social participation and learning, personal development, vocational preparation, and community participation. The PSE's primary focus is to prepare individuals with ID to obtain competitive and integrated jobs while living in their communities of choice upon program completion. While the PSE program has been in operation for almost 10 years, many lessons have been learned to develop and enhance innovative practices that lead to more integrated employment outcomes. Therefore, the purpose of this practice brief is to share specific innovative practices used in this PSE program related to a) career interests/assessments, b) person centered planning practices to determine support needs, c) advising and college course planning, d) setting up internships and paid work experiences, e) evaluation and observation of work performance, and f) connecting back to the community with video resumes.

\section{Career interests and assessments}

When facing unknown roads ahead and several new lifelong goals, it is important to have a roadmap to explore your strengths and guide you every step of the way. The first step is taking time to get to know each student or client based on his or her overall strengths, preferences, interests, and needs. This can include both formal and informal assessments, observations, interviews/questionnaires, environmental analysis, and curriculum-based assessments. All these resources will help summarize previous work history, current career interests, skills already developed, and skills to expand in relation to future career goals. While there are many ways to obtain this information, we start by gathering an initial admissions videos, informal interviews with students about past and future work experiences, and then move to using more formal assessments like the Your Employment Selections (YES!), Brigance Transition Skills Inventory, and related inventories within the Pro-Ed Employment and Career Planning Transition Series. In order to visually tie all the goals and information gathered together, it is organized with the student taking the lead to develop their own personalized academic roadmaps so everyone can reference this and work together to achieve these goals through personcentered planning processes.

\section{Person centered planning practices to determine support needs}

Although there are no specified guidelines, person centered planning (PCP) should be at the forefront of any transition planning and occur regularly thereafter on a pre-determined schedule. This allows families to know how and when to be involved as well as holding individuals, families, and supports accountable for responsibilities, and gives a specific time for reflecting and evaluating progress toward goals. In our PSE program, we use a Planning Alternative Tomorrows with Hope (PATH) that provides a twoyear plan regarding their (a) desired course of study, (b) supports accessed in previous work experiences, and (c) individual goals to be attained through on or off campus work experiences. After initial interviews and academic roadmaps have been developed, program staff continue working with the individual and family members to create an Individualized Plan for College Participation (IPCP) which includes specific personalized goals leading to more long term achievements. These are goals phrased and reflected upon in monthly PCP meetings led by the students and attended by the team of supports that regularly work with the student. There are five parts to our PCP meetings including:

1. Stories of success (e.g., visiting goals and noting progress on goals listed in IPCP)

2. What is working well (e.g., strategies or routines that have helped lead to success)

3. What could be improved (e.g., review goals and note progress on IPCP)

4. Next Steps (e.g., future steps for increased independence or transition, fading of supports)

5. Other items or questions? (e.g., logistics, celebrating successes or evaluating behavior based on the university code of conduct)

\section{Advising and college course planning}

The academic roadmap described above is comprised of five topic areas that encourage the student to (a) examine who they are, (b) who they want to be in the future, (c) leisure interests, (d) desired skills, and (e) career and job preferences. The last section of the form asks the student to form two to three long-term goals of what he or she hopes to accomplish before finishing college. This easy to follow graphic organizer also serves as a great curriculum 


\begin{tabular}{|l|}
\hline Who am I? (Describe self; skills; \\
strengths; personality) \\
- Outgoing \\
- Creative \\
Like to talk to other people \\
and make them laugh \\
- Like to be around people \\
Prom queen at my high \\
- Preol \\
- Happy \\
- Friendly \\
\hline
\end{tabular}

\begin{tabular}{|l|}
\hline Interests \& Curiosities \\
\& Hobbies \\
- Loves to attend sporting \\
events \\
- Intramural soccer \\
- Karaoke \\
- Shopping \\
- Crime/criminal behavior; \\
police, detectives \& the legal \\
system \\
- Traveling \\
\end{tabular}

ACADEMICS

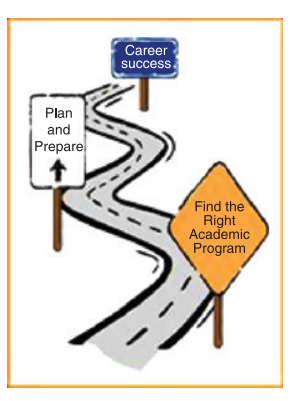

\section{Skills Desired}

- Cooking: using stove timers and buttons

- Working with a team

- Sign language

- Learning how to drive

- Meeting new people

- Money skills: getting correct change, not getting ripped off.

- Measuring/measurement

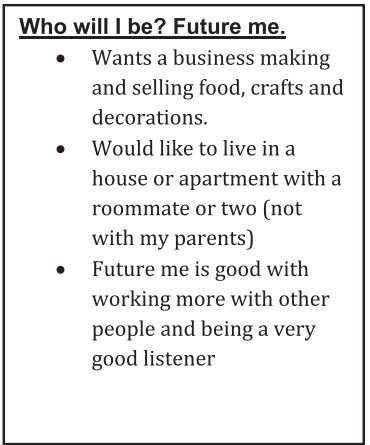

Careers \& Jobs

- Intern with a retail clothing store/ anything to do with design \& fashion

- Vet assistant (working with animals)

- Food service with drive thru and taking orders/money

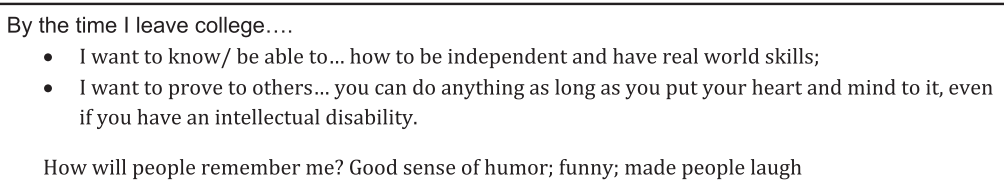

- I want to know/ be able to... how to be independent and have real world skills;

- I want to prove to others... you can do anything as long as you put your heart and mind to it, even if you have an intellectual disability.

How will people remember me? Good sense of humor; funny; made people laugh

Fig. 1. Example of academic roadmap used in the PSE program.

guide for college courses the students can take to help them visualize their future during and after the college experience (see Fig. 1). From information on the academic roadmap, everyone works together to create a list of college courses initially and each semester that can be audited in relation to the student's overall career goals.

\section{Setting up internships and paid work experiences}

Many universities offer a wide variety of jobs that parallel those found in many communities. In fact, a college campus is typically a community within itself. While work-based experiences can take many forms (e.g., career exploration, job shadowing, volunteer work, service learning, internships, apprenticeships, and paid employment), this PSE program's top priority is to seek paid employment and internships on campus or off-campus during all four semesters as part of the two year PSE experience. So how does it all happen? The PSE program has a half-time Career Development Coordinator who approaches potential employers with the idea of gaining part-time jobs (typically 10 hours per week that align with the student's long term career goals). The initial work sites are chosen based on student's personal career goals and strengths as well as what they can also offer to the employer or internship sites. When it is not possible to secure all paid work experiences, we strive for placement in various campus venues closely related to the student's career goals so they can also learn the vocational skills needed to secure a future paid position. Regardless of the outcome whether paid or unpaid, potential employers are approached with the goal of the student gaining valuable work experience while on or off campus and expanding their vocational preparation and social skills. Once a job or internship experience is secured, it is important 
for everyone involved to clarify all the job tasks and requirements up front to avoid misunderstandings. This process begins with the memorandum of agreement with the employer. It is a chance where the Career Development Coordinator and employer brainstorm assigned tasks or accommodations necessary with the new employee as well as skills to build for future career goals.

Above and beyond the semester long work-based experiences we also encourage other volunteer work and service learning opportunities so students can work along side and learn directly from their college peers while simultaneously expanding their social skills and career possibilities. Some students on the job need more support than others, but most times support needs are determined as a team together in monthly PCP meetings.

\section{Evaluation and observation of work performance}

As the work tasks are introduced and routines established, there are several ways to go about monitoring work performance and each PSE program should find a method that works best for their students. For our PSE program, this is accomplished through individualized task/work cards. These task cards are used to self-monitor and document overall job performance and provide the student with ongoing feedback about their work performance.

Data collected on the job from the task/work cards are also discussed at monthly PCP meetings. This determines if more independence can be given while on the job as the student shows mastery with job performance. As this occurs, the role of natural supports can be shifted more to coworkers or the employer. The Career Development Coordinator or natural supports working with the PSE program observe biweekly to determine mastery of job performance and continued support needs.

The final and more summative way we evaluate work performance is to solicit feedback directly from employers. To do this, at least once or twice a semester, we ask employers in both paid jobs and unpaid internships to provide us with feedback on each student's performance. Items addressed in this evaluation include a number of job-related skills from punctuality, productivity, and enthusiasm to hygiene and motivation (see Fig. 2). Evaluation results are shared with the students with Excellent being an "A", Very Good being a " $\mathrm{B}$ " etc. If any areas are rated as
Acceptable "C" or Poor "D" then a plan for improvement is created with the student and support team together during monthly PCP meetings. Many topics are then addressed and practiced in scheduled one-onone times with natural supports (undergraduate peers) with multiple opportunities each week to practice using role-plays, repetition, and technology to remediate or strengthen the vocational area(s) of concern.

\section{Connecting back to the community with video resumes}

During the second and final year of the PSE program, we work together to narrow the search for a permanent job placement in the student's home or chosen future community. Starting the first semester, we strive to achieve these outcomes by networking with students and their families, community businesses, and when at all possible vocational rehabilitation (VR). Each member of this team brings a unique and valuable expertise to the transition planning process.

As many would agree, the student and family are the most important members of the team. The student has lots of choices and responsibilities from deciding their career path, determining the location of where they will live after graduation, level of support needs, and locating community resources to aid community job placements. Using this input, family members are asked to help with the job-hunting process and on-going conversations with their son or daughter about job and life goals post graduation. Families are also an invaluable resource for networking with community members they already have connections with in order to identify job opportunities and access public transportation. Students and families are also responsible for sharing this information throughout the four semesters with PSE staff on a regular basis and connecting to businesses during semester and summer breaks to open doors of paid work opportunities. Across the four semesters, PSE staff also work to gather employer interviews and work experiences organized in short video clips to highlight overall job skills learned and strengths of the student.

It is often a selling point that our PSE graduates leave with a self-narrated video resume (5 mins or less in length) and updated traditional resume to capture their strengths, work ethic, motivation to do a job well, employer interviews, references, and to highlight the graduates desire to go above and beyond the job requirements. By sharing these characteristics 


\section{Employment Internship Evaluation}

Please complete and return it to . Your time is much

\section{appreciative!}

\section{Student Name:}

Your Name:

Internship Site and Activity:

\begin{tabular}{|l|l|l|l|l|l|}
\hline \multicolumn{1}{|c|}{$\begin{array}{c}\text { Work Related } \\
\text { Behavior }\end{array}$} & $\begin{array}{c}\text { Excellent } \\
\text { (demonstrated 90\% } \\
\text { to 100\% of the time) }\end{array}$ & $\begin{array}{c}\text { Very Good } \\
\text { (demonstrated 80\% } \\
\text { to 89\% of the time) }\end{array}$ & $\begin{array}{c}\text { Acceptable } \\
\text { (demonstrated 70\% } \\
\text { to 79\% of the time) }\end{array}$ & $\begin{array}{c}\text { Poor } \\
\text { (demonstrated } \\
6 \% \text { to 69\% of } \\
\text { the time) }\end{array}$ & $\begin{array}{c}\text { Unacceptable } \\
\text { (demonstrated less } \\
\text { than 59\% of the time) }\end{array}$ \\
\hline $\begin{array}{l}\text { Attendance and } \\
\text { punctuality }\end{array}$ & & & & & \\
\hline $\begin{array}{l}\text { Hygiene and } \\
\text { grooming }\end{array}$ & & & & & \\
\hline Communication skills & & & & \\
\hline $\begin{array}{l}\text { Relations with } \\
\text { supervisor and co- } \\
\text { workers }\end{array}$ & & & & & \\
\hline $\begin{array}{l}\text { Motivation to work } \\
\text { and learn }\end{array}$ & & & & & \\
\hline $\begin{array}{l}\text { Ability to accept and } \\
\text { follow directions }\end{array}$ & & & & & \\
\hline $\begin{array}{l}\text { Attention to task and } \\
\text { quality of } \\
\text { performance }\end{array}$ & & & & & \\
\hline $\begin{array}{l}\text { Production speed or } \\
\text { quantity }\end{array}$ & & & & & \\
\hline Problem solving skills & & & & & \\
\hline Enthusiasm on the job & & & & \\
\hline $\begin{array}{l}\text { Self-confidence in } \\
\text { ability to learn }\end{array}$ & & & & \\
\hline
\end{tabular}

Please feel free to offer any comments you wish about the PSE program and this particular student.

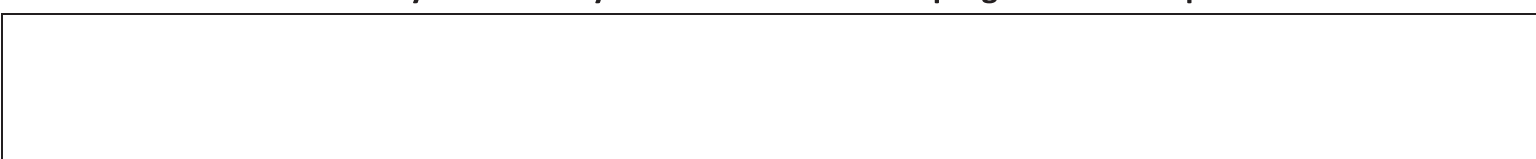

Please contact , Career Development Coordinator, at xxx-xxx-xxxx

if you have questions or concerns about this evaluation. Thank you!

Fig. 2. Example of employer evaluation used in the PSE program.

with potential employers firsthand, we are often able to help our graduates begin jobs that can lead to long lasting careers and the most integrated employment opportunities.
Being successfully employed in inclusive communities will not only allow greater independence, but will provide productive members of society who fulfill a more desired and inclusive quality of life full of 
endless possibilities. Sometimes that simply evolves best by starting with higher expectations and one's willingness to take risks to provide initial work opportunities.

\section{Conflict of interest}

The authors have no conflict of interest to report.

\section{Reference}

Grigal, M., Hart, D., Smith, F. A., Domin, D., Sulewski, J., \& Weir, C. (2015). Think College National Coordinating Center: Annual report on the transition and postsecondary programs for students with intellectual disabilities (2013-2014). Boston, MA: University of Massachusetts Boston, Institute for Community Inclusion. 